\title{
Survey of Natural Radioactivity Levels in Ilex paraguariensis (St. Hil.) by Gamma-ray Spectrometry
}

\author{
Viviane Scheibel* and Carlos Roberto Appoloni \\ Departamento de Física; Universidade Estadual de Londrina; C.P.6001; scheibel@uel.br; appoloni@uel.br; \\ 86051-990; Londrina - PR -Brasil
}

\begin{abstract}
The mate tea (Ilex paraguariensis - St. Hil.) is a beverage broadly cultivated and consumed in Brazil. The radioactive traces present in three trademarks of toasted mate tea produced at the south of Brazil were analyzed. Measurements were carried out by gamma-ray spectrometry. The average value for the ${ }^{40} \mathrm{~K}$ activity measured for marks A, B and C was $1216 \pm 8,1047 \pm 14$ and $666 \pm 13 \mathrm{~Bq} \cdot \mathrm{kg}^{-1}$, respectively. The ${ }^{137} \mathrm{Cs}$ activity was lower than the limit of detection.
\end{abstract}

Key words: Gamma-ray spectrometry; Marinelli beaker; mate tea, ${ }^{40} \mathrm{~K}$.

\section{INTRODUCTION}

Ilex paraguarisiensis (St. Hil.) or mate tea is a typically acidic soil growing species with its natural distribution restricted to $3 \%$ of the South American territory, embracing Brazil, Paraguay and Argentina (Reissmann et al., 1999). A long time before the knowledge of its chemical composition, mate tea was used due to its properties, as increased the fatigue resistance and relieved thirst or hunger (UFRGS, 2003). During this period, it was used to prepare infusions beverages broadly consumed. Usually, the processed herb products were selected, purchased in markets and commercialized for export to several countries (Carducci et al., 2000).

The mate tea is very rich in minerals elements that are essential to human nutrition and realize specific functions in the organism (Reissmann et al., 1999), as stimulant effects on the human central nervous system, as well as anti-rheumatic and diuretic effects (Carducci et al., 2000). The chemical composition of mate tea leaves extracts have specific characteristics, for example, the leaves with an age ranging around six months counts high level of methylxanthines and it could be used in energetic drinks formulation (Esmelindro et al., 2004).

An important element appearing to be significant in these properties is potassium, which is associated to sodium and regulates the muscle system function and the cardiac rhythm (Almeida et al., 2002). Living organisms need potassium in their bodies, which is incorporated through alimentation. However, approximately $0.0118 \%$ of Earth potassium is compound by the ${ }^{40} \mathrm{~K}$ radioisotope. In this way, each organic material ingested will present a little quantity of radioactivity (Biral, 2002).

The purpose of the present study was to measure natural radiation levels of commercial toasted mate tea produced at Paraná State, Brazil and determine the concentration of these radionuclides.

\footnotetext{
${ }^{*}$ Author for correspondence
} 


\section{MATERIALS AND METHODS}

The samples were analyzed using a gamma-ray spectrometer consisting of an HPGe detector with $10 \%$ relative efficiency, an ORTEC 673 amplifier and an ORTEC Trump ${ }^{\mathrm{TM}} 8 \mathrm{~K}$ multichannel card. The software used for analysis and reduction of the gamma ray spectra was MAESTRO ${ }^{\mathrm{TM}}$, version 3.2. The energy resolution of the ${ }^{60} \mathrm{Co} 1332.46$ $\mathrm{keV}$ gamma ray line was $2.41 \mathrm{keV}$. Sample geometry used was a Marinelli beaker of $2.1 \mathrm{~L}$ made by Ga-Ma \& Associates, INC, of a special material with a low radioactivity background. Sample and detector were positioned inside a shield compound by lead $(50 \mathrm{~mm})$, iron $(2.5 \mathrm{~mm})$, aluminum $(2 \mathrm{~mm})$ and acrylic $(2 \mathrm{~mm})$.

The activity of each radionuclide was calculated according to IAEA directions (IAEA - Techn. Rep. 295, 1989) and was given by:

$$
A=\frac{N_{L}}{\varepsilon \cdot P_{\gamma} \cdot m \cdot t},
$$

where:

$A \rightarrow$ sample activity concentration in Bq. $\mathrm{kg}^{-1}$

$N_{L} \rightarrow$ net counts measured under the photopeak

$\varepsilon \rightarrow$ system detection efficiency

$P_{\gamma} \rightarrow$ absolute transition probability by gamma decay for the selected energy

$m \rightarrow$ sample mass in kilograms

$t \rightarrow$ counting time in seconds

The lower limit of detection (LLD) was given by Eq. (2), for 95\% confidence level (IAEA - Techn. Rep. 295, 1989):

$$
L L D=\frac{N_{L \min }}{\varepsilon \cdot P_{\gamma} \cdot m \cdot t},
$$

where $\mathrm{N}_{\mathrm{Lmin}}$ was the minimum net area of the measured spectrum:

$$
N_{L \min }=4.66 \sqrt{F_{C}}
$$

and $F_{c}$ was the Compton background in the region of the selected gamma line in the sample spectrum.

Commercial samples of Ilex paraguariensis (St. Hil.), known as mate tea, were a blend of dried stalks and leaves from regions of Paraná State, packed in plastic with paper bags containing $200 \mathrm{~g}$ of commercial product (A - Leão Junior S. A., lot 263, validity: 09/19/2002; measured: 01/2002; B Moinhos Unidos Brasil - Mate S. A., lot 009/00-
03, validity: 09/25/2002, measured: 02/2002 and C - Schuur \& Cia Ltda., lot 06/2000, validity: 08/2002, measured: 03/2002) and were purchased from stores. After statistical inference (Melquiades and Appoloni, 2001; 2002) it was decided to prepare six samples of each lot, with approximately $0.6 \mathrm{~kg}$, of three different brands of the commercially mate tea, so as to represent each one with a $90 \%$ confidence level.

The bags of tea were homogenized and accommodated in Marinelli beakers without previous treatment. The beakers were completely filled, sealed and aged 40 days to achieve the secular equilibrium before their measurement by gamma-ray spectrometry. The counting time for the samples and background was 172800 seconds. The detection efficiency was determined in a previous work (Melquiades and Appoloni, 2001; 2002), developed with the same geometry and detector system, using a certified ${ }^{152}$ Eu source and IAEA - 375 and IAEA - 326 certified samples.

The whole sample volume into the Marinelli beaker emits natural radiation and part of this emitted radiation is attenuated by the matrix and does not reach the detector. To take this into account, self-attenuation corrections were carried out with the aid of tea leaves chemical composition data (Taiz and Zeiger, 1998). ${ }^{40} \mathrm{~K}$ did not present cascade transitions, it produces a single line, hence, it was not necessary to employ the coincidence summing correction. For the other radionuclides, this correction was smaller or of the order of the activity deviation, becoming also unnecessary.

\section{RESULTS AND DISCUSSION}

Table 1 shows the average activities and deviations of the three mate tea brands. For mate tea A, the activity for ${ }^{232}$ Th was close to its deviation and ${ }^{40} \mathrm{~K}$ presented activity of $1216 \pm 8$ $\mathrm{Bq} \cdot \mathrm{kg}^{-1}$. Both mate tea B and C presented only the ${ }^{40} \mathrm{~K}$ line, with $1047 \pm 14 \mathrm{~Bq} \cdot \mathrm{kg}^{-1}$ and $666 \pm 13$ Bq. $\mathrm{kg}^{-1}$, respectively.

Table 2 presents the ${ }^{40} \mathrm{~K}$ tea data from the literature. From the measured potassium content for each tea, the ${ }^{40} \mathrm{~K}$ activity was calculated. 
Table 1 - Average activities and standard average deviation with $95 \%$ confidence of the analyzed mate tea samples.

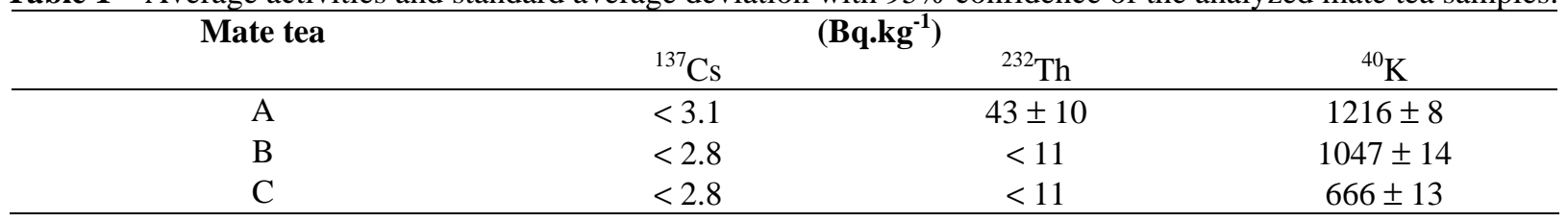

Table 2 - Tea data for ${ }^{40} \mathrm{~K}$ activities from the literature.

\begin{tabular}{lcc}
\hline Sample & $\left(\mathbf{B q \cdot \mathbf { k g } ^ { - 1 }}\right)$ & Reference \\
\hline Black tea & 461 & Isasa, 1980 \\
Green tea & 358 & Isasa, 1980 \\
Mate tea & 380 & Carducci, 2000 \\
Mate tea & 519 & Reissmann, 1999 \\
Tea leaves & 734 & Ahmad, 1983 \\
Tea leaves & 479 & Kasrai, 1977 \\
Tea leaves & 688 & Fujinaga, 1979 \\
\hline
\end{tabular}

In all measured tea samples, the ${ }^{40} \mathrm{~K}$ activities values (Table 1) were higher than those reported in literature (Table 2). However, mate tea $\mathrm{C}{ }^{40} \mathrm{~K}$ activities were comparable to tea leaves from Japan (Fujinaga, 1979), which presented 688 Bq. $\mathrm{kg}^{-1}$ and to tea leaves from Pakistan (Ahmad et al., 1983) that had 734 Bq. $\mathrm{kg}^{-1}$. The other tea activities from the literature were lower than the mate tea $\mathrm{C}$, one as black tea $\left(461 \mathrm{~Bq} \cdot \mathrm{kg}^{-1}\right)$ and green tea $\left(358 \mathrm{~Bq} \cdot \mathrm{kg}^{-1}\right.$ ) from Madrid (Isasa and Marquina, 1980), mate tea $\left(380 \mathrm{~Bq} \cdot \mathrm{kg}^{-1}\right)$ from Argentina (Carducci et al., 2000), tea leaves (479 Bq. $\mathrm{kg}^{-1}$ ) from Iran (Kasrai, 1977). The result of mate tea $\left(519\right.$ Bq.kg $\left.{ }^{-1}\right)$ from Paraná State, Brazil was the closest value compared to the mate tea $\mathrm{C}$ of the present work, which could be due to type of soil formation, since this tea came from the same geographic region (Reissmann et al., 1999). Mate tea brands $\mathrm{A}$ and $\mathrm{B}$ presented ${ }^{40} \mathrm{~K}$ activities (Table 1) more than twice the values reported in the literature.

Potassium has also been reported in four medicinal plants from Ceará State, Brazil (Almeida et al., 2002), which is usually consumed as tea. From the potassium content of each medicinal plant, its ${ }^{40} \mathrm{~K}$ activity was calculated: "Capim-santo" - 65 Bq.kg1 , "Cidreira" - 75 Bq.kg ${ }^{-1}$, "Hortelã-rasteira" - 83 Bq. $\mathrm{kg}^{-1}$ and "Mastruço" - $122 \mathrm{~Bq} \cdot \mathrm{kg}^{-1}$. Each of these tea herbs presented much lower ${ }^{40} \mathrm{~K}$ activities compared to the results for mate tea.

${ }^{137} \mathrm{Cs}$ activities for all samples were lower than the limit of detection and very inferior to the trading limit adopted in Brazil for ${ }^{134} \mathrm{Cs}$ and ${ }^{137} \mathrm{Cs}$ activities (maximum of $600 \mathrm{~Bq} \cdot \mathrm{kg}^{-1}$ ) (CNEN NE-3.01, 1988). These were no exists in literature tea leaves data for ${ }^{232} \mathrm{Th}$ and ${ }^{137} \mathrm{Cs}$ activities to compare with the limits found in this work, as at Table 1.

Potassium remains under close homeostatic control in the body, and, therefore its level is almost constant. As the metabolic balance maintains the $\mathrm{K}$ body level irrespective of intake quantities, the amount of ${ }^{40} \mathrm{~K}$, which is $1.17 \times 10^{-4}$ of the natural abundance, will be also nearly constant. The annual ${ }^{40} \mathrm{~K}$ equivalent dose in tissues of the body is $165 \mu \mathrm{Sv} \cdot \mathrm{y}^{-1}$ for adults and the total ${ }^{40} \mathrm{~K}$ effective dose from inhalation and ingestion is $170 \mu \mathrm{Sv}$ (UNSCEAR, 2000). Due to this reason, there was no problem of mate tea ingestion presenting the activities levels found in this work.

\section{CONCLUSIONS}

The majority of ${ }^{40} \mathrm{~K}$ activities measured in the present work were higher than those reported in the literature. For mate tea $\mathrm{C}\left(666 \pm 13 \mathrm{~Bq} \cdot \mathrm{kg}^{-1}\right)$ 
presented the closest values compared to the literature with $519 \mathrm{~Bq} \cdot \mathrm{kg}^{-1}$ for the same geographic region. For the remaining mate tea brands, the measured activities in this work were more than twice the values reported in the literature.

\section{ACKNOWLEDGEMENTS}

The authors would like to thank CAPES/MECBRAZIL for the financial support.

\section{RESUMO}

Uma bebida amplamente consumida e cultivada no Brasil é o chá-mate (Ilex paraguariensis - St. Hil). Foram analisados os traços radioativos de três marcas comerciais de chá-mate tostado produzidos no sul do Brasil. As medidas foram realizadas por espectrometria gama. Os valores médios para as atividades medidas do ${ }^{40} \mathrm{~K}$, para as marcas A, B e $\mathrm{C}$ foram $1216 \pm 8,1047 \pm 14$ e $666 \pm 13 \mathrm{~Bq} \cdot \mathrm{kg}^{-1}$, respectivamente. As atividades para o ${ }^{137} \mathrm{Cs}$ foram menores que o limite mínimo de detecção.

\section{REFERENCES}

Ahmad, S., Chaudhary, M. S., Mannan, A., Qureshi, I. H. (1983), Determination of toxic elements in tea leaves by instrumental neutron activation analysis. $J$. Radioanal. Chem. 78, 375-383.

Almeida, M. M. B., Lopes, M. F. G., Nogueira, C. D. M., Magalhães, C. E. C., Morais, N. M. T. (2002), Determinação de nutrientes minerais em plantas medicinais. Ciência Tecnologia Alimentos, Campinas. 22, 94-97.

Biral, A. R. (2002), Radiações ionizantes para médicos, físicos e leigos. Ed. Insular Ltda, Florianópolis.
Carducci, C. N., Dabas, P. C., Muse, J. O. (2000), Determination of inorganic cations by capillary ion electrophoresis in Ilex paraguariensis (St. H.), a plant used to prepare tea in South America. J. AOAC Intern. 83, 1167-1173.

CNEN - Comissão Nacional de Energia Nuclear (1988), $\mathrm{NE}-3.01$.

Esmelindro, A. A., Girardi, J. S., Mossi, A., Jacques, R. A., Dariva, C. (2004), Influence of Agronomic Variables on the Composition of Mate Tea Leaves (Ilex paraguariensis) Extracts Obtained from $\mathrm{CO}_{2}$ Extraction at $30^{\circ} \mathrm{C}$ and 175 bar. J. Agric. Food Chem. 52 (7), 1990-1995.

Fujinaga, E. (1979), Anal. Chem. Acta. 110, 75

IAEA - International Atomic Energy Agency (1989), Techn. Rep. No 295.

Isasa, M. E. T., Marquina, A. D. (1980), Minerals Elements in commercial teas - I) Macroelements. Anal. Bromatol., XXXII-4, 361-366.

Kasrai, M. (1977), J. Radioanal. Chem. 41, 73

Melquiades, F. L., Appoloni, C. R. (2001), Radiation of powdered milk produced at Londrina, PR, Brazil. Radiat. Phys. Chem. 61, 691-692.

Melquiades, F. L., Appoloni, C. R. (2002), ${ }^{40} \mathrm{~K},{ }^{137} \mathrm{Cs}$ and ${ }^{232} \mathrm{Th}$ activities in Brazilian milk samples measured by gamma ray spectrometry. Indian J. Pure Ap. Phys. 40, 5-11.

Reissmann, C. B., Radomski, M. I., Quadros, R. M. B. (1999), Chemical composition of Ilex paraguariensis St. Hil. under different management conditions in seven localities of Paraná State. Brazilian Arch. Biol. Techn. 42, 187-194.

Taiz, L., Zeiger, E. (1998), Plant Physiology, 2nd Ed., Sinauer Associates, Inc., Publishers. Sunderland, Massachusetts, pp. 104.

UFRGS - Universidade Federal do Rio Grande do Sul. Instituto de Ciência e Tecnologia de Alimentos. Available $<$ http://www.clubedoterere.com.br/composicao/>. Accessed on Aug. 2003.

UNSCEAR - United Nations Scientific Committee on the Effects of Atomic Radiation (2000), UNSCEAR 2000 Report. 